\title{
EVALUATION OF SERVICE QUALITY BASED ON RURAL HOUSEHOLDS' VISITORS - SERBIAN CASE STUDY
}

\author{
Tamara GAJIĆ ${ }^{\mathrm{a}}$, Aleksandra VUJKO ${ }^{\mathrm{a}, \mathrm{b}, *}$, Tatiana N. TRETIAKOVA ${ }^{\mathrm{a}}$, \\ Marko D. PETROVIĆ ${ }^{\mathrm{a}, \mathrm{c}}$, Milan RADOVANOVIĆc ${ }^{\mathrm{a}, \mathrm{c}}$, Darko VUKOVIĆ ${ }^{\mathrm{c}, \mathrm{d}}$
}

\author{
${ }^{a}$ Institute of Sports, Tourism and Service, South Ural State University, 76 Lenin Avenue, Chelyabinsk \\ 454080, Russia; tamara.gajic.1977@gmail.com; ttn1@mail.ru \\ ${ }^{\mathrm{b}}$ Novi Sad Business School, Vladimira Perića Valtera 4, 21000 Novi Sad, Serbia; \\ aleksandravujko@yahoo.com \\ c Geographical Institute "Jovan Cvijić" SASA, Djure Jakšića 9, 11000 Belgrade, Serbia \\ ${ }^{\mathrm{d}}$ National Research University Higher School of Economics, St. Petersburg School of Economics and \\ Management, Department for Finance, Kantemirovskaya St. 3A, Office 331, 194100 Saint Petersburg, \\ Russia \\ "Correspondence: aleksandravujko@yahoo.com; Tel.: +381-64-914-2645
}

Cite this article: Gajić, T., Vujko, A., Tretiakova, T.N., Petrović, M.D., Radovanović, M., Vuković, D. (2019). Evaluation of Service Quality Based on Rural Households' Visitors - Serbian Case Study. Deturope, 11(2), 4-21.

\begin{abstract}
The unfavorable economic and political situation that has lasted since the end of the 20th century has implications for tourism and economic development of Serbia. In today's conditions of the extremely complex economic situation, the quality of business operations is seen as a significant long-term factor of stabilization in the market and providing a firm position among its competitors. Rural tourism in Serbia should contribute to the preservation of the rural environment, demographic condition, and cultural heritage, but also to the economic placing of Serbia in a better market position in the region. The aim of this study is to focusing on perception of importance and quality of services in rural tourism households and based on the analyzed data it attempts to confirm certain assumptions relating to the quality of provided services. The authors conducted their research survey on 164 respondents in 15 municipalities in Serbian countryside.

Keywords: evaluation, rural tourism, quality, Serbia
\end{abstract}

\section{INTRODUCTION}

Serbia has a quality and diverse basis for the successful development of rural tourism, extreme natural and social values, rich cultural and historical heritage and favorable geographic and traffic position. Rural tourism in Serbia should contribute to the development of environment, but also to economically motivate the local population to remain in the countryside. Many studies focus on rural tourism and its impact on economic development. Rural tourism is associated with notions of rusticity and authenticity, which greatly depend on natural environment, arts, heritage and tradition of agrarian societies (Bouchon \& Rawat, 2016). Empirical studies have grown in profusion during the past ten years and have focused on the causality relationship between rural tourism and economic growth (Brida \& Pulina, 2010). 
Rural tourism and diversification of economic activities in the countryside are an important, integral part of sustainable development (Vujko, Petrović, Dragosavac, \& Gajić, 2016; Vujko \& Gajić, 2014a; Petrović, Blešić, Vujko, \& Gajić, 2017). The future development of rural tourism is reflected in possession of a large number of untouched natural resources and scenic rural communities that offer beauty, peace, and tranquility (Bouchon \& Rawat, 2016). Korsching \& Allen (2004) indicated that many rural communities are struggling to maintain their economic and social vigor; fewer still are experiencing any type of growth or development. Increasing quality importance in rural tourism is determined mainly by increased competition, customer requirements and complexity of products and processes made in order to achieve them (Chris, Susan, Hamin, \& Albert, 2017). When the country fell into bad economic and political situation, the entire economic and social system collapsed, which is slowly coming out and it carries such a state (Vujko \& Gajić, 2014b). Renovation of traditional rural households, as well as improvement of rural tourism is supported by the Ministry of Agriculture, Forestry and Water Management of the Republic of Serbia, but also the local population. Likewise, the quality of provided services is a current topic in the world.

The authors argue that research with others, since goods and services are increasingly becoming commoditized, businesses should provide meaningful experiences to their customers in order to add value to their offerings (Berry, Carbone, \& Haeckel., 2002). According to some research, the attitude of tourists on the quality of tourist services in rural tourism gets a greater importance. Rural tourism is closely linked with the quality of services provided and the evidence is as much the price of human labor (Bouchon \& Rawat, 2016). One of the main factors that positively affecting the success of tourism destinations is the quality of tourism services and many countries are adopting a policy of quality service in order to consolidate themselves as an alternative in these highly competitive markets (Go \& Govers, 2000). The authors in this research, guided by certain hypotheses, pointed to the current status of rural areas in Serbia and the existing level of service quality, using a variety of statistical, quantitative and qualitative methods, and research carried out by other institutions. The survey was conducted in 15 municipalities of the country (the municipalities of Vojvodina, Southeast and Southwest Serbia), among 164 respondents belonging to the category of tourists.

In line with the aim of research there are the following hypotheses:

H1. Rural tourism in Serbia is not satisfactory compared to the total tourist development measured by the accomplished number of nights spent by tourists.

H1a. There is significant income from tourism and investment in all regions of the state of Serbia for the development of rural tourism. 
H1b. There is a statistically significant difference in the development of rural tourism in Serbia and the region.

H2. Satisfaction of tourists' content and quality of the tourist offer of rural households in Serbia is an indicator of the development of rural tourism.

$\mathrm{H} 2 \mathrm{a}$. There was a statistically significant difference between the attitudes of visitors of rural households in relation to the scale of importance (expectations) and the perception of the elements of quality accommodation offer, in the direction to exceed the expectations of visitors to their perception.

\section{THEORETICAL FRAMEWORK AND HYPOTHESIS DEVELOPMENT}

\section{Rural tourism - experiences and data from the global and Serbian situation}

According to Wood (2002), rural tourism supports various activities that are based on natural and cultural values of the local community enabling original experiences for the tourists during their stay. Smith and Eadington (1992) consider rural tourism as part of alternative practices that include 'forms of tourism that are consistent with natural, social and community values and which allow both hosts and guests to enjoy positive and worthwhile interaction and shared experiences. Many studies indicate segments that include rural tourism, and often states that this form of tourism includes a wide range of attractions and activities that usually take place in non-agricultural or urban settings (Lane, 1994; Frochot, 2005). Tourism in rural areas affects the socioeconomic revitalization, the diversification strategy of the industry is justified by tourism, environmental and economic reasons.

Hall (2004) points out in his research that rural tourism and in both developed and developing countries often serves to stimulate regional economic activity. Long (1998) proposes that rural areas are perceived as for tourists and places of safety surrounded by open spaces and natural beauty places where everyone is treated with respect and kindness. According to Idelhadj, Mateos, and García (2012), rural tourism is part of the economy and contributes to the economic development of the country and additional benefit increases. In principal, rural tourism destinations essentially have distinct characteristics: wide-open spaces, low levels of tourism development, and opportunities for visitors to directly experience agricultural and/or natural environments (Snieška, 2014; Demirović, Košić, Surd, Žunić, \& Syromiatnikova, 2017). According to the statistical analysis of the competent authorities of the European Commission, the European Union EU-27 can be described by the following indicators in 2013: 12 million farms, 172 million hectares of agricultural land, 25 million people 
are employed in agricultural production. On average, one farm has 14.3 hectares of agricultural land and earns 25,450 euros of profit a year. The unsynchronized and uncoordinated development of offer, incompatible with other entities, formed the incomplete and insufficiently differentiated offer of rural tourism in Serbia (Petrović et al., 2017b). Regarding the specialized literature in the tourism domain, it was written much about the relationship between tourism and development, despite the increasing social and economic significance and the use of tourism as a development strategy in developing countries (Titu, 2016). Rural areas comprise $85 \%$ of Serbia and about $43 \%$ of the total population live there. As for the participation of the rural population in the total population of Serbia the situation is as follows: in Vojvodina there is about $44.62 \%$ of the rural population, Central Serbia $42.40 \%$, the area of Belgrade $18.9 \%$, $55.4 \%$ in other areas. According to the scope and structure of available farmland, Serbia is among the European countries with favorable land resources, since it has 0.7 ha of agricultural land, or 0.45 ha of arable land per capita.

At the same time, the ratio of surface area of arable land and permanent crops according to the area of meadows and pastures (71:29\%) is among the more favorable compared to other European countries. The aim of this paper is to explore the possibility of achieving high quality in order for Serbia to reach the European quality standards and joined the European Association of rural countries, bearing in mind that this association has an annual income of 13 billion euros from rural supply and up to 17 billion euros from the sale of souvenirs. Compared with data from 2006, when there were 140 households in 44 villages, with 750 beds, in 2014 the figure increased significantly, and the turnover in rural tourism in 119 villages, 164 households and 1,628 beds. On average, in the framework of rural tourism in Serbia there are 408,580 overnight stays, or about $6.2 \%$ of the total number of overnight stays in Serbia. Domestic visitors account for almost $90 \%$ of all visitors in rural tourism in Serbia. The results from the 2011 Census show that the demographic trends in Serbia, especially in its rural areas are increasingly unfavorable. In the period from 2002 to 2011 there was a decline of the rural population to 311,139 inhabitants $(10.9 \%)$.

\section{Quality and consumer satisfaction}

The interest in the quality of provided services is increasing from year to year, and studies have shown that service quality is a prerequisite for success and survival in today's competitive environment (Ghobadian, Speller, \& Jones, 1994). The most typical way of measuring service quality is the Servqual scale and the five dimensions (reliability, responsiveness, assurance, empathy, tangibles (Baumann, Burton, Elliott, \& Kehr, 2004). That the quality of service and 
customer satisfaction are becoming imperative in any successful show and their research in this area (Narayan, Rajendren, Sai, \& Gopalan, 2014; Rajaratnam, Munikrishnan, Sharif, \& Nair, 2014; Lo, Songan, Mohamad, \& Yeo, 2011; Moutino, Albayrak, T., \& Caber, 2012; Moreira \& Campos, 2010), as providing high quality service and ensuring tourist satisfaction are recognized as important factors influencing the success of the tourism industries (Chen, Lee, Chen, \& Huang, 2011). In addition to evaluating service quality, assessing tourists' satisfaction with destination is important because it influences the choice of destination, the decision to return (Brown \& Churchill, 1993). Earlier studies indicate a positive reaction of consumers and their satisfaction with the quality service they receive (Lo, Songan, Mohamad, \& Yeo, 2011; Chen, Lee, Chen, \& Huang, 2011). However, some studies (Hernández-Maestro, MuñozGallego, \& Requejo, 2007) found no significant relationship between service quality and tourist satisfaction. Chang points out customers' perceptions of experience quality (Chen, Lee, Chen, \& Huang, 2011) or identified and measured dimensions (Kim, Knutson, \& Beck 2011). So far, researchers have mainly studied perceived service quality and customer satisfaction (Olsson, Friman, Pareigis, \& Edvardsson 2012). An assessment of tourists' satisfaction of the rural destinations visited can assist rural tourism players to have a better understanding of tourists' perceptions and focus their efforts to enhance tourists' positive experiences in the rural destinations (Rozman, Potocnik, Pazek, Borec, Majkovic, \& Bohanec, 2009).

\section{METHODOLOGY}

\section{Sources of data and methodology of research}

The first survey-based research regarding the level of development of rural tourism in Serbia was taken from the Ministry of Agriculture, Forestry and Water Management, the rural development sector. The second part of the research is related to the quality of services in rural areas of Serbia, estimated by the tourist consumers. The research was carried out by the authors of the survey in 15 rural municipalities in Serbia. Descriptive statistical analysis was applied to calculate the average score on the issues and determinants of quality. This method was applied to calculate the arithmetic mean, mode, median and standard deviation. The basic formula for calculating the arithmetic mean as follows:

$$
M=\frac{\sum X}{N}
$$

where $\mathrm{M}$ represents the arithmetic mean, collapsed to the sum of results from first to last, and $\mathrm{N}$ number of results. Standard deviation shows a high degree of deviation of the individual 
values of characteristics from the arithmetic mean and always a positive value or zero. The standard deviation can be described as the square root of the average of the sum of squared deviations. Mod (or dominant value) is the value of characteristics that are most common in the numerical series, or label that has the highest frequency. Numerical series may have one or more modes, and if all of the same frequency, the series has no modus. Median (or central value) is a value in the range of results, sorted by size, is located right in the middle. T-test for independent samples was used to compare mean values of the results and determine the statistical significance of their differences. The independent samples are those samples following the measurements which are not correlated.

\section{Description of the sample survey}

Study 1. Determining the current state of development of rural tourism in Serbia and position in the region - a comparative analysis with direct competitors in the region

The research methodology is based upon surveys of the Ministry of Agriculture, Forestry and Water Management, Rural Development Sector. The recent data, which are newer than those presented in the work of the year 2014, are not available and they were not surveyed. Two surveys were conducted. The first survey was conducted on a sample of 248 rural tourism households that provide accommodation for tourists, distributed in 166 villages in 19 municipalities. The other survey refers to other service providers and other operators in rural tourism. The survey covered a total of 163 buildings, of which there are 21 household, 75 restaurants of various types, 43 commercial companies and 24 facilities that provide other services such as galleries, museums, agencies and the like. The aim is to indicate the current state of development of rural tourism in Serbia, Lower Danube region, South Banat, Central Serbia, Eastern Serbia.

Table 1 Actual number of overnight stays in rural areas in Serbia (\% share compared to the total number from 2007 to 2016).

\begin{tabular}{l|lllllllll}
2007 & 2008 & 2009 & 2010 & 2011 & 2012 & 2013 & 2014 & 2015 & 2016 \\
\hline $21.71 \%$ & $20.54 \%$ & $20.85 \%$ & $20.31 \%$ & $21.45 \%$ & $22.42 \%$ & $20.83 \%$ & $21.32 \%$ & $20.66 \%$ & $20.02 \%$
\end{tabular}

Source: Author's calculations based on statistical data of the Republic Institute for Statistics.

The average number of domestic tourists per year (per household) is 422 , while there are on average 66 foreign tourists. The most visited regions are Western and Central part of Serbia. Based on Table 1 one can see that there are no large fluctuations in the change of the number 
of nights in the recent years. The data can be confirmed by the main hypothesis H1, where the authors started from the premise that the development of rural tourism is very low compared to the total tourist development of the state (on average slightly above $20 \%$ ).

Table 2 Revenue generated from the provision of accommodation, food and sales of domestic products.

\begin{tabular}{|c|c|c|c|c|}
\hline Region Serbia & East Serbia & Central Serbia & $\begin{array}{l}\text { Danube } \\
\text { region }\end{array}$ & Southern Banat \\
\hline $\begin{array}{l}\text { Generated revenue from } \\
\text { accommodation, meals and sale of } \\
\text { domestic products (EURO) }\end{array}$ & EUR 93,200 & EUR 329,000 & EUR 904,000 & EUR 153,000 \\
\hline
\end{tabular}

Source: Ministry of Agriculture, Forestry and Water Management, Republic of Serbia, Rural Development Sector.

The revenue from rural tourism in Serbia is presented in Table 2. The highest revenues are achieved in the Danube region with 904,000 EUR from the provision of accommodation, food and sales of domestic products. The amount of realized funds for encouraging rural tourism and diversifying economic activities in rural areas tends to increase during the period from 2014 to 2016. The total amount of realized revenues in the period was 91,580,215 dinars (Table 3). The number of beneficiaries of funds increased, with 22 users in 2006 and 110 users in 2008. The total number of beneficiaries for the period 2014 - 2016 is 173 . The highest number of beneficiaries of the funds are individuals - registered farmers (total 141), followed by citizens' associations (23), legal entities - entrepreneurs (7) and cooperatives (2).

Table 3 Distribution of funds by region

\begin{tabular}{|c|c|c|c|c|c|c|c|c|}
\hline Region & Western & Vojvodina & Central & EASTERN & BELGRADE & SOUTHERN & Kosovo & TOTAL \\
\hline 2006 & 8.867 .538 & $5,989,547$ & 7.158 .205 & 813.011 & $4,998,814$ & 0 & 0 & 27.827 .116 \\
\hline 2008 & 23.932 .657 & 3.572 .737 & 3.286 .540 & 4.968 .632 & 280.347 & 400.000 & 283.500 & 36.724 .413 \\
\hline TOTAL & 49.598 .155 & 12.164 .271 & 11.535 .615 & 11.324 .275 & 5.279 .161 & 1.377 .238 & 283.500 & $91,580,215$ \\
\hline$\%$ & 54.2 & 13.3 & 12.6 & 12.4 & 5.8 & 1.5 & 0.3 & 100 \\
\hline
\end{tabular}

Source: Ministry of Agriculture, Forestry and Water Management, Republic Serbia, Rural Development Sector.

ins for investments in rural tourism, it is practically reduced to investment in public infrastructure, which primarily has a social character, and then the significance of the development of tourism. This analysis shows that the development of rural tourism depends on the overall socio-economic development. The total income of rural tourism generated by tourist rural households and other supporting entities is small, or in terms of individual subject is not insignificant. Hypothesis H1a is refuted by the data indicating that the revenues are generated, but not to a significant extent to encourage further economic and economic development. 
Table 4 The position of Serbia in the region

\begin{tabular}{|c|c|c|c|}
\hline Region & Serbia & Croatia & Slovenia \\
\hline Size of rural areas (\% of total territory) & $85 \%$ & $90 \%$ & $90 \%$ \\
\hline Rural population (\% of total population) & $48 \%$ & $44 \%$ & $57 \%$ \\
\hline Population in rural areas (population/ $/ \mathrm{km}^{2}$ ) & $84 \%$ & $79 \%$ & $87 \%$ \\
\hline The average unemployment rate in rural areas & $21 \%$ & $18 \%$ & $9 \%$ \\
\hline Number of households with the tourist offer & 300 & 400 & 600 \\
\hline The average number of nights per year & 150.000 & 220.000 & 300.000 \\
\hline Average retention of tourists (days) & 2.8 & 2.8 & 3.7 \\
\hline $\begin{array}{l}\text { The total accommodation capacity (number of } \\
\text { beds) }\end{array}$ & 8.000 & 8.900 & 6.000 \\
\hline Average capacity utilization & $40 \%$ & $57 \%$ & $70 \%$ \\
\hline Average revenue per household (euro/year) & 2.500 & 5.000 & 10.000 \\
\hline
\end{tabular}

Source: Author's calculations based on research.

The comparative analysis of economic indicators (Table 4) can lead to the conclusion that all three countries have a percentage of rural territories of equal size but of different degrees of development. Rural population percentage is highest in Slovenia with 57\% of the total population, followed by Serbia with $48 \%$, and then by Croatia with $44 \%$. Also, the population in rural areas is the largest in Slovenia (Petrović, Gelbman, Demirović, Gagić, \& Vuković 2017c) and the lowest in Croatia. The average number of overnight stays annually is also the largest in Slovenia, and the utilization of capacity in the region is also at a higher level. The position of Serbia in the region among the closest and most similar competitors across all geographic, commercial and economic parameters are at the lowest level. However, when it comes to the hypothesis $\mathbf{H 1 b}$, we can say that there are differences in development in the region, but it is not significant in all segments. The actual number of nights is significantly lower, while the other parameters are approximate to the states in the region. Slovenia has a much smaller number of beds in relation to Serbia, but the higher utilization.

\section{Study 2. Service quality in rural tourism in Serbia}

The authors carried out the survey in Serbia in the rural areas of Vojvodina, Southeast and Southwest Serbia, in the period from May to December 2016. There was the total of 15 municipalities with 164 respondents: Subotica, Sombor, Novi Sad, Irig, Pancevo, Valjevo, Kosjeric, Gornji Milanovac, Knić, Čajetina, Majdanpek, Negotin, Knjaževac, Pirot and Dimitrovgrad in three tourism clusters: Vojvodina, Western Serbia, Eastern Serbia (all clusters have been defined by the National Tourism Development Strategy of the Republic of Serbia).

The survey questionnaire contains a total of 45 questions. The seven closed questions refer to the socio-demographic characteristics of visitors of rural households, while the two 
questions, which are also closed, relate to the matter of informing tourists of rural households. The remaining 36 questions relate to the ranking of different positions according to the criteria of importance and satisfaction of tourists. In order to measure the attitudes of tourists, a fivepoint Likert scale of importance has been used. The paper presents the data factor analysis of relevance and satisfaction of seven subscales. For the assessment of relevance of the gap between importance and satisfaction of the factors of quality of tourists, the t-test for dependent samples is used.

Table 5 Structure of respondents by gender and age

\section{STRUCTURE GENDER AGE STRUCTURE STRUCTURE}

\begin{tabular}{l|cccccccc}
\hline TOTAL 164 & Male & Female & $<21$ & $12-30$ & $31-40$ & $41-50$ & $51-$ & $>60$ \\
& & & & & & & 60 & \\
FREQUENCY & 70 & 94 & 3 & 82 & 50 & 17 & 6 & 6 \\
PERCENT & $42.7 \%$ & $57.3 \%$ & $1.8 \%$ & $50.0 \%$ & $30.5 \%$ & $10.4 \%$ & $3.7 \%$ & $3.7 \%$
\end{tabular}

Source: Author's calculations based on research.

Based on the analysis of the structure (Table 5) of the respondents the dominating number of the respondents are students with the share of $42.1 \%$. The respondents whose primary business is tourism accounts for $26.2 \%$, while the lowest share of the respondents is those who work in in the sector of agriculture $-3 \%$, and crafts $-6.1 \%$, whereas there are $22.6 \%$ of the respondents working in other sectors. As for the level of earnings there is the following situation: only $2 \%$ of respondents had more than 2,000 euros of monthly salary, followed by $2.6 \%$ of the respondents with the salary ranging from 1000 to 2000 euros, then $20.9 \%$ earning from 600 1000 euros, and finally $16.3 \%$ with the salary from 400 to 600 euros. With earnings of 200-400 euros per month there was $30.1 \%$, and below 200 euros a month there was $28.1 \%$ of them.

\section{RESULTS AND DISCUSSION}

\section{Forming subscales - the results of the factor analysis}

The factor analysis, with using the method of extraction - Analysis of the main components (PCA), has determined one-dimensional and factorial validity of each of the factors. According to the high value of Cronbach's Alpha Reliability Coefficient, a high degree of reliability of items for each of the factors can be established (Table 6). 
Table 6 Basic psychometric characteristics of the instruments and key for calculating scores / factors

\begin{tabular}{|c|c|c|c|c|}
\hline & Subscales & Items & $\begin{array}{c}\text { Cronbach's } \\
\text { Alpha }\end{array}$ & Nitems \\
\hline \multirow[t]{7}{*}{ Importance } & Personal responsibility & v1-v7 & .784 & 7 \\
\hline & Accompanying offer & v8-v11 & .566 & 4 \\
\hline & Relations with tourists & v12-v17 & .751 & 6 \\
\hline & Basic requirements & v18-v22 & .757 & 5 \\
\hline & The material elements & v23-v28 & .678 & 6 \\
\hline & Security & v29-v32 & .712 & 4 \\
\hline & Empathy & v33-v36 & .718 & 4 \\
\hline \multirow[t]{7}{*}{ Satisfaction } & Personal responsibility & $\mathrm{z} 1-\mathrm{z} 7$ & .885 & 7 \\
\hline & Accompanying offer & z8-z11 & .647 & 4 \\
\hline & Relations with tourists & z12-z17 & .721 & 6 \\
\hline & Basic requirements & $z 18-z 22$ & .845 & 5 \\
\hline & The material elements & $z 23-z 28$ & .683 & 6 \\
\hline & Security & $z 29-z 32$ & .718 & 4 \\
\hline & Empathy & $z 33-z 36$ & .746 & 4 \\
\hline
\end{tabular}

Source: Author's calculations based on research.

The analysis of descriptive indicators for scores on the dimensions of importance and satisfaction has been conducted. The analysis shows that the distribution of the weight of a normal distribution of scores, or scores are slightly negative asymmetrical. The respondents tend to positively evaluate all dimensions. Dimensions of importance tend to group around the average value, and satisfaction kurtosis, which means that their results are uniformly dispersed. According to the descriptive indicators, we conclude that the factor of personal liability estimated highest marks in terms of importance and aspects of satisfaction by tourists (means were 31.33 and 29.94 respectively).

The second and third most important factors are material elements and relations with tourists, while in terms of satisfaction these factors are in reverse order (Table 6). The lowest score was recorded by a factor of safety on both scales. The results of the descriptive analysis of the importance of the evaluated quality indicators are presented in the Table 7 and include average value score tourists $(\mathrm{M})$, standard deviation $(\mathrm{SD})$, median $(\mathrm{Me})$, inter-quarter range $(\mathrm{Q})$, mod (Mod) and the number of respondents $(\mathrm{N})$. The values of arithmetic mean in a sample of tourists range from 2.87 to 4.73 . The lowest arithmetic average of the approximate assessment is 3 , while the highest arithmetic mean is the closest to score 5.

Thus, it can be concluded that the tourists gave estimates for the importance of defined quality indicators from 3 to 5 (high expectations). This conclusion is proven by the Mod value, since in $87 \%$ of the items the highest median score 5 is given. The analysis showed that in $67 \%$ of the questions the highest score was given, which corresponds to the previously derived conclusion. In addition, since these values are very approximate, we can say that it is a 
symmetrical distribution of frequencies, whose standard deviation is relatively large, and in the range of 0.57 to 1.29 .

Table 7 Descriptive statistics for issues relating to the importance of quality of service indicators under evaluation

\begin{tabular}{|c|c|c|c|c|c|c|}
\hline & M & SD & Me & $\mathbf{Q}$ & Mod & $\mathbf{N}$ \\
\hline Home team meets every requirement in a fair and timely manner. & 4.54 & 0.7 & 5 & 1 & 5 & 164 \\
\hline The host knows his/her job, he/she is good at it, performs flawlessly. & 4.52 & 0.72 & 5 & 1 & 5 & 164 \\
\hline The host comes out to meet the guests to help them solve the problem. & 4.63 & 0.59 & 5 & 1 & 5 & 162 \\
\hline The host is always concerned with the requirements of the customer. & 4.39 & 0.8 & 5 & 1 & 5 & 162 \\
\hline When a problem occurs, the host quick accesses to its solution. & 4.48 & 0.72 & 5 & 1 & 5 & 163 \\
\hline The host meets the requirements without delay. & 4.35 & 0.77 & 5 & 1 & 5 & 164 \\
\hline $\begin{array}{l}\text { In the household there is always present someone who is ready to take care of the } \\
\text { requirements. }\end{array}$ & 4.46 & 0.82 & 5 & 1 & 5 & 164 \\
\hline Our host provides quality meals. & 4.62 & 0.7 & 5 & 1 & 5 & 164 \\
\hline The host has the role of tour guide and provide us with information. & 3.99 & 1.08 & 4 & 2 & 5 & 164 \\
\hline Our host provides domestic and traditionally prepared meals. & 4.42 & 0.84 & 5 & 1 & 5 & 163 \\
\hline $\begin{array}{l}\text { In the household there is a possibility of including a guest in the domestic activities } \\
\text { (collection of fruit, sightseeing domestic animals, preparing brandy, food). }\end{array}$ & 3.72 & 1.24 & 4 & 2 & 5 & 162 \\
\hline Household members know the traditions, customs and history of their city. & 4.34 & 0.94 & 5 & 1 & 5 & 164 \\
\hline $\begin{array}{l}\text { Household members are engaged in activities that make our stay more complete } \\
\text { (souvenirs made of natural materials, weaving workshops or connection, etc.). }\end{array}$ & 3.61 & 1.16 & 4 & 2 & 4 & 162 \\
\hline $\begin{array}{l}\text { Household members give us good advice and suggestions regarding activities that } \\
\text { make our stay complete. }\end{array}$ & 4.1 & 0.96 & 4 & 1 & 4 & 164 \\
\hline $\begin{array}{l}\text { Household members are providing us with interesting information about the local } \\
\text { food. }\end{array}$ & 4.05 & 0.97 & 4 & 2 & 5 & 164 \\
\hline Household members treat us with kindness and warmth. & 4.73 & 0.57 & 5 & 0 & 5 & 164 \\
\hline Household members are friendly toward us. & 4.7 & 0.57 & 5 & 0 & 5 & 164 \\
\hline Furniture and household furnishings are well preserved. & 4.24 & 0.78 & 4 & 1 & 5 & 163 \\
\hline The room in which we were placed (rooms) is comfortable. & 4.49 & 0.72 & 5 & 1 & 5 & 163 \\
\hline $\begin{array}{l}\text { Common areas in households (corridors, kitchen, dining room, lobby ...) are well } \\
\text { preserved. }\end{array}$ & 4.5 & 0.72 & 5 & 1 & 5 & 163 \\
\hline Marketing household is authentic. & 4.09 & 0.95 & 4 & 1 & 5 & 164 \\
\hline The cost of housing in accordance with the quality. & 4.51 & 0.72 & 5 & 1 & 5 & 162 \\
\hline $\begin{array}{l}\text { The interior of the household (furniture, ceilings, lighting, flooring, etc.) is cozy, } \\
\text { homely and authentic. }\end{array}$ & 4.39 & 0.78 & 5 & 1 & 5 & 164 \\
\hline $\begin{array}{l}\text { Exterior households (facade, garden, courtyard) is attractive and in line with the } \\
\text { rural environment. }\end{array}$ & 4.36 & 0.8 & 5 & 1 & 5 & 163 \\
\hline The host was dressed in traditional costume. & 2.87 & 1.23 & 3 & 2 & 3 & 163 \\
\hline The rooms in which we are placed are clean. & 4.72 & 0.61 & 5 & 0 & 5 & 163 \\
\hline The whole household is clean. & 4.68 & 0.68 & 5 & 0 & 5 & 157 \\
\hline Additional space (the yard, garden, terrace, barbecue) is clean. & 4.55 & 0.68 & 5 & 1 & 5 & 162 \\
\hline \multirow[t]{2}{*}{ Security measures have been taken (e.g. A safe deposit box of money, etc.). } & 3.53 & 1.24 & 4 & 2 & 4 & 161 \\
\hline & M & SD & Me & Q & Mod & $\mathbf{N}$ \\
\hline The hosts take care of the safety of guests. & 4.52 & 0.73 & 5 & 1 & 5 & 164 \\
\hline Each part of the household is marked with the symbol. & 3.59 & 1.29 & 4 & 2 & 5 & 160 \\
\hline Access road to the household was marked with the signs. & 4.24 & 1 & 5 & 1 & 5 & 161 \\
\hline The hosts speak a foreign language. & 3.78 & 1.22 & 4 & 2 & 5 & 161 \\
\hline The hosts are trying to ensure that the guests are well understood. & 4.4 & 0.83 & 5 & 1 & 5 & 160 \\
\hline $\begin{array}{l}\text { The hosts take care of the customer, taking into account his personal desires and } \\
\text { needs. }\end{array}$ & 4.43 & 0.78 & 5 & 1 & 5 & 164 \\
\hline If you have a group of guests, the host has an individual approach to each. & 4.07 & 0.96 & 4 & 1 & 5 & 164 \\
\hline
\end{tabular}

Source: Author's calculations based on research

The analysis of these parameters leads to the conclusion that tourists give the primary importance to the following items: friendliness, clean rooms, hospitability of hosts, problem solving, good meals, clean additional space, meeting the demands of tourists properly and in a timely manner, the host knows his/her job, he/she is good at it and performs it flawlessly, the hosts care about the safety of guests and price of housing in accordance with the quality. On 
the other hand, tourists in rural areas of Serbia assessed the following items as the least important: the host is dressed in traditional costume, safety measures (safe), each part of the household was marked with the sign, household members are engaged in activities (souvenirs made of natural materials, workshops weaving or embroidery), the possibility of including the guest in domestic activities (collection of fruit, sightseeing domestic animals, participation in the preparation of brandy, wine, local food), knowledge of a foreign language and the host has the role of tour guide and provides information on services.

Table 8 Descriptive statistics for the questions relating to the satisfaction of the assessed indicator of quality services

\begin{tabular}{|c|c|c|c|c|c|c|}
\hline & $M$ & $S D$ & $M e$ & $Q$ & Mod & $N$ \\
\hline Home team meets every requirement in a fair and timely manner. & 4.38 & 0.74 & 5 & 1 & 5 & 164 \\
\hline The host knows his/her job, he/she is good at it, performs flawlessly. & 4.28 & 0.8 & 4 & 1 & 5 & 164 \\
\hline The host comes out to meet the guests to help them solve the problem. & 4.42 & 0.77 & 5 & 1 & 5 & 163 \\
\hline The host is always concerned with the requirements of the customer. & 4.22 & 0.84 & 4 & 1 & 5 & 161 \\
\hline When a problem occurs, the host quick accesses to its solution. & 4.26 & 0.84 & 4 & 1 & 5 & 164 \\
\hline The host meets the requirements without delay. & 4.15 & 0.8 & 4 & 1 & 4 & 164 \\
\hline $\begin{array}{l}\text { In the household there is always present someone who is ready to take care of the } \\
\text { requirements. }\end{array}$ & 4.24 & 0.82 & 4 & 1 & 5 & 164 \\
\hline Our host provides quality meals. & 4.39 & 0.86 & 5 & 1 & 5 & 163 \\
\hline The host has the role of tour guide and provide us with information. & 3.95 & 0.98 & 4 & 2 & 4 & 164 \\
\hline Our host provides domestic and traditionally prepared meals. & 4.4 & 0.89 & 5 & 1 & 5 & 162 \\
\hline $\begin{array}{l}\text { In the household there is a possibility of including a guest in the domestic activities } \\
\text { (collection of fruit, sightseeing domestic animals, preparing brandy, food). }\end{array}$ & 3.65 & 1.19 & 4 & 2 & 4 & 161 \\
\hline Household members know the traditions, customs and history of their city. & 4.17 & 0.9 & 4 & 1 & 5 & 163 \\
\hline $\begin{array}{l}\text { Household members are engaged in activities that make our stay more complete } \\
\text { (souvenirs made of natural materials, weaving workshops or connection ...). }\end{array}$ & 3.45 & 1.1 & 3 & 1 & 3 & 161 \\
\hline $\begin{array}{l}\text { Household members give us good advice and suggestions regarding activities that } \\
\text { make our stay complete. }\end{array}$ & 4.04 & 0.88 & 4 & 2 & 4 & 164 \\
\hline $\begin{array}{l}\text { Household members are providing us with interesting information about the local } \\
\text { food. }\end{array}$ & 4.06 & 0.94 & 4 & 2 & 5 & 164 \\
\hline Household members treat us with kindness and warmth. & $\mathbf{M}$ & SD & Me & $\mathbf{Q}$ & Mod & $\mathbf{N}$ \\
\hline Household members are friendly toward us. & 4.62 & 0.66 & 5 & 1 & 5 & 164 \\
\hline Furniture and household furnishings are well preserved. & 4.62 & 0.69 & 5 & 1 & 5 & 164 \\
\hline The room in which we were placed (rooms) is comfortable. & 4.01 & 0.89 & 4 & 2 & 4 & 163 \\
\hline $\begin{array}{l}\text { Common areas in households (corridors, kitchen, dining room, lobby ...) are well } \\
\text { preserved. }\end{array}$ & 4.13 & 0.9 & 4 & 1 & 5 & 163 \\
\hline Marketing household is authentic. & 4.14 & 0.90 & 4 & 1 & 5 & 163 \\
\hline The cost of housing in accordance with the quality. & 3.71 & 1.1 & 4 & 2 & 5 & 161 \\
\hline $\begin{array}{l}\text { The interior of the household (furniture, ceilings, lighting, flooring, etc.) is cozy, } \\
\text { homely and authentic. }\end{array}$ & 4.1 & 0.93 & 4 & 1 & 5 & 162 \\
\hline $\begin{array}{l}\text { Exterior households (facade, garden, courtyard) is attractive and in line with the } \\
\text { rural environment. }\end{array}$ & 4.16 & 0.88 & 4 & 1 & 5 & 164 \\
\hline The host was dressed in traditional costume. & 4.07 & 0.98 & 4 & 2 & 5 & 163 \\
\hline The rooms in which we are placed are clean. & 2.77 & 1.2 & 3 & 2 & 3 & 161 \\
\hline The whole household is clean. & 4.45 & 0.77 & 5 & 1 & 5 & 162 \\
\hline Additional space (the yard, garden, terrace, barbecue) is clean. & 4.4 & 0.82 & 5 & 1 & 5 & 156 \\
\hline \multirow[t]{2}{*}{ Security measures have been taken (e.g. A safe deposit box of money, etc.). } & 4.27 & 0.8 & 4 & 1 & 5 & 160 \\
\hline & 3.09 & 1.26 & 3 & 2 & 3 & 162 \\
\hline The hosts take care of the safety of guests. & 4.18 & 0.9 & 4 & 1 & 5 & 163 \\
\hline Each part of the household is marked with the symbol. & 3.36 & 1.12 & 3 & 1 & 3 & 158 \\
\hline Access road to the household was marked with the signs. & 3.63 & 1.21 & 4 & 2 & 5 & 164 \\
\hline The hosts speak a foreign language. & 3.34 & 1.22 & 3 & 1 & 3 & 158 \\
\hline The hosts are trying to ensure that the guests are well understood. & 4.21 & 0.86 & 4 & 1 & 5 & 162 \\
\hline $\begin{array}{l}\text { The hosts take care of the customer, taking into account his personal desires and } \\
\text { needs. }\end{array}$ & 4.33 & 0.76 & 4 & 1 & 5 & 164 \\
\hline If you have a group of guests, the host has an individual approach to each. & 3.98 & 0.96 & 4 & 2 & 4 & 162 \\
\hline
\end{tabular}

Source: Author's calculations based on research 
The arithmetic means of items relating to the satisfaction (Table 8) with the indicators of quality of services ranges from 2.77 to 4.62 . The lowest value of the arithmetic mean is 3 , whereas the highest assessment is 5 . According to the analysis mode, it can be concluded that $68 \%$ of respondents gave the highest rating for the items, while $16 \%$ of the items obtained scores 4 and 3. If we compare it with the importance (Table 7) of analysis, where $87 \%$ of the items received the highest rating, we observe that there is a mismatch between expectations and actual tourist satisfaction. The analysis shows that the median $22 \%$ of the items received a rating of 5 , and score 4 was given to $63 \%$ of the items. It is the unsymmetrical distribution of the variance in the range from 0.66 to 1.26 . According to the parameters of descriptive statistics, the evaluation of satisfaction of tourists with every item was defined in the questionnaire. According to this assessment, the tourists were given the highest ratings for the following items according to the criteria of personal satisfaction: kindness, hospitality, clean rooms, problem solving, traditional cuisine, good meals, clean household. Based on the above, the hypothesis $\mathrm{H} 2$ is accepted, which indicates that the tourists' satisfaction with the content and quality of the tourism offer of rural households in Serbia is an indicator of the development of rural tourism. Thus, dissatisfaction with the elements of the tourist offer is in line with the low level of development of this form of tourism.

The Table 9 provides an overview of the analysis of descriptive indicators for scores on the dimensions of importance and satisfaction. The analysis shows that the distribution of the scores has a tendency to a normal distribution of scores, but the scores are slightly negatively asymmetrical. The respondents tend to positively evaluate all dimensions. Dimensions of importance tend to group around the mean value and satisfaction kurtosis, which means that their results are uniformly dispersed.

Table 9 Descriptive indicators for scores on the quality aspects of the tourism offer

\begin{tabular}{|c|c|c|c|c|c|c|c|c|c|c|}
\hline & Subscale & $M$ & $S D$ & $M e$ & $Q$ & Min & $\operatorname{Max}$ & $s$ & $K$ & $N$ \\
\hline \multirow{7}{*}{ Importance } & Personal responsibility & 31.33 & 3.45 & 32 & 6 & 21.00 & 35.00 & -0.79 & -0.16 & 164 \\
\hline & Accompanying offer & 16.74 & 2.61 & 17 & 3.97 & 8.00 & 20.00 & -0.99 & 0.89 & 164 \\
\hline & Relations with tourists & 25.53 & 3.56 & 26 & 4.75 & 13.00 & 30.00 & -0.98 & 0.90 & 164 \\
\hline & Basic requirements & 21.81 & 2.82 & 22 & 4 & 12.00 & 25.31 & -0.81 & 0.15 & 164 \\
\hline & The material elements & 25.59 & 3.05 & 26 & 4 & 17.00 & 30.30 & -0.78 & 0.03 & 164 \\
\hline & Security & 15.90 & 3.14 & 16 & 4.75 & 6.00 & 20.00 & -0.69 & 0.03 & 164 \\
\hline & Empathy & 16.79 & 2.90 & 17 & 4 & 6.00 & 20.00 & -1.04 & 0.89 & 164 \\
\hline \multirow{7}{*}{ Satisfaction } & Personal responsibility & 29.94 & 4.33 & 30.5 & 6 & 17.00 & 35.00 & -0.78 & -0.04 & 164 \\
\hline & Accompanying offer & 16.28 & 2.78 & 17 & 5 & 9.00 & 20.00 & -0.55 & -0.50 & 164 \\
\hline & Relations with tourists & 24.98 & 3.43 & 25,5 & 5 & 16.00 & 30.22 & -0.53 & -0.36 & 164 \\
\hline & Basic requirements & 20.11 & 3.74 & 20 & 5 & 9.00 & 25.65 & -0.56 & -0.33 & 164 \\
\hline & The material elements & 24.17 & 3,46 & 25 & 5 & 14.00 & 30.29 & -0.61 & -0.09 & 164 \\
\hline & Security & 14.25 & 3.34 & 14 & 5 & 4.00 & 20.00 & -0.26 & -0.39 & 164 \\
\hline & Empathy & 15.51 & 3.02 & 16 & 5 & 7.00 & 20.00 & -0.34 & -0.64 & 164 \\
\hline
\end{tabular}

Source: Author's calculations based on research. 
The factor of Personal responsibility is given the highest marks in terms of importance and satisfaction aspects by the tourists who visit the rural areas of Serbia (means were 31.33 and 29.94 respectively). The second and third most important factors are Material elements and Relations with tourists, while the terms of satisfaction of these factors are in reverse order. The lowest score was recorded by a factor of safety on both scales.

In order to test the significance of the gap between importance and satisfaction ratings by factors of quality of tourist offer is applied t-test for paired samples. For all differences of scores, importance is higher than satisfaction, which is shown in the table with the positive difference between the arithmetic mean of the samples (Table 10).

Table 10 The significance of the gap between importance and satisfaction scores determined by t-test for paired samples

\begin{tabular}{|c|c|c|c|c|c|c|c|}
\hline \multirow[t]{2}{*}{$\begin{array}{l}\text { Importance - } \\
\text { satisfaction }\end{array}$} & \multicolumn{2}{|c|}{ Descriptive indicators } & \multicolumn{3}{|c|}{ t-test for depend samples } & \multicolumn{2}{|c|}{$\begin{array}{l}\text { Correlation } \\
\text { measurements }\end{array}$} \\
\hline & Difference $\mathbf{M}$ & $\begin{array}{c}\text { SD } \\
\text { (difference) }\end{array}$ & $\mathbf{t}$ & df & $\mathbf{p}$ & $\mathbf{r}$ & $\mathbf{p}$ \\
\hline Personal responsibility & 1.40 & 3.86 & 4.63 & 163.00 & $0.00 * *$ & .527 & .000 \\
\hline Accompanying offer & 0.37 & 2.52 & 1.86 & 163.00 & 0.07 & .566 & .000 \\
\hline Relations with tourists & 0.55 & 3.52 & 2.00 & 163.00 & $0.05^{*}$ & .490 & .000 \\
\hline Basic requirements & 1.69 & 3.95 & 5.49 & 163.00 & $0.00 * *$ & .299 & .000 \\
\hline The material elements & 1.43 & 3.59 & 5.08 & 163.00 & $0.00 * *$ & .396 & .000 \\
\hline Security & 1.65 & 3.55 & 5.94 & 163.00 & $0.00 *$ & .4 .00 & .000 \\
\hline Empathy & 1.28 & 3.34 & 4.89 & 163.00 & $0.00 *$ & 3.64 & .000 \\
\hline
\end{tabular}

Source: Author's calculations based on research. Note: ${ }^{*} \mathrm{p}<0.05 ; * *$ when $\mathrm{p}<0.01$

According to the t-test, accompanying offer has no statistical significance on the security level of $1 \%$. The smallest difference in arithmetic means has a factor Relations with tourists which indicates that the expectations of the tourists were approximate to satisfaction they get in their relations with their hosts. Large differences have been observed in the factors of Safety, Material elements, Personal liability, whereas the highest difference was for the factor Basic requirements (Table 10).

This statistical result shows that tourists who visit the area of rural tourism in Serbia are dissatisfied with furniture, space and cost of accommodation. Because the hosts in Serbia have limited investment opportunities due to the crisis in the country, such reaction of tourists is expected. The results of t-test for dependent samples showed that the quality of service and accommodation in rural tourist areas of Serbia is not satisfactory, because there are significant differences in satisfaction scores achieved according to the expectations of tourists, in the direction that the expectations were significantly higher. The hypothesis H2a: There was a statistically significant difference between the attitudes of visitors of rural households in relation to the scale of importance (expectations) and the perception of the elements of quality 
accommodation offer, in the direction that the expectations of visitors surpass their perception is proved.

\section{CONCLUSION}

Rural tourism is a growing tourism industry in many parts of the world, but mainly in developed countries, and has substantially expanded since the 1970s, both in terms of demand and of supply (Lane, 2009; Lee \& Nam, 2005). On the supply side, underpinning this general support for rural tourism is the assumption that it provides a number of potential benefits to rural areas (Hall, Mitchell, \& Roberts, 2003; Roberts \& Hall, 2001). The task of the research was to determine the level of development of rural tourism in Serbia and quality of the services. In order to rank the position of Serbia for more precisely and more valid analysis, rural tourism in Serbia is compared with Croatian and Slovenian rural tourism since these European countries are the most similar to the demographic and geographic structure of Serbia. Comparative analysis included a comparison of both the basic economic indicators and the legal, organizational and other indicators that pointed to underdevelopment of the Serbian rural tourism in relation to these two countries (H1b). The results of comparative analysis showed a serious problem of depopulation of villages in Serbia, poorly developed municipal infrastructure and low productivity of rural economy. Hypothesis H1a that there are significant revenues from tourism in Serbia is refuted, because the development of tourism (H1), i.e. the number of overnights in rural tourism of Serbia, is at a low level.

Therefore, this analysis focuses on the surveys on satisfaction and expectations of tourists in certain rural areas in Serbia. The analysis of the data obtained in descriptive statistics leads to the conclusion that the tourists have given the highest scores for the following items according to the criteria of personal satisfaction: kindness and warmth of the hosts, clean rooms, the host comes out to meet the guests and help them solve the problem, the host provides domestic and traditionally prepared meals, complete household is clean, host provides good meals. Based on the above, the hypothesis $\mathbf{H 2}$ is accepted, which says that the tourist satisfaction with the content and quality of the tourism offer of rural households in Serbia is an indicator of the development of rural tourism. Thus, dissatisfaction with the elements of the tourist offer is in line with the low level of development of this form of tourism. The results of t-test for dependent samples showed that the quality of service and accommodation is not satisfactory, because there are significant differences in satisfaction scores achieved according to the expectations of tourists, in the direction that the expectations were significantly higher. The authors of the research proved the hypothesis that there is a mismatch between expectations and actual 
satisfaction of tourists who visit the rural areas of Serbia (H2a). The conclusion is not surprising because they match the similar findings in other scientific studies (Chang \& Horng, 2010; Getz \& Page, 1997; Wang \& Qu, 2006). The deviation tourist satisfaction from their expectations suggests that the quality of services in rural regions of Serbia is not sufficient to meet the requirements of demand. The development of rural areas in Serbia is faced with a number of limiting factors (Petrović et al., 2017b), among which the following may be distinguished: scarce knowledge about new approaches to development of the rural economy; he lack of an institutional framework (especially legislation), which would provide a coordinating role of the state and greater involvement of local authorities in the integrated rural development; underdeveloped infrastructure; inadequate diversification of activities; dominance of sectoral policies, etc.

According to the identified obstacles to the development of rural tourism in Serbia it is possible to extract guidelines for future development and in the following way: finding mechanisms to prevent depopulation of villages and rural areas in the development concept of tourism (strengthening infrastructure, raising the attractiveness of the region, the enrichment of tourist facilities, diversification of rural economy), standardization and uniformity in the sector of rural tourism (e.g. categorization), more and better integration of agriculture and tourism in the planning documents and in practice, greater participation of the owners of rural households, as well as education and awareness of local people about the possibilities of rural tourism (continuing education), preserving the original rural environment, finding better solutions for the protection of cultural monuments in villages and building which nourishes the values of traditional architecture, building better economic incentive policy that would help accelerate the development of rural tourism and overcoming legal restrictions and changes to the legal norms that hinder people in business within the rural tourist household.

\section{Acknowledgements}

The research was supported by Ministry of Education, Science and Technological Development, Republic of Serbia (Grant III 47007) and by the Act 211 Government of the Russian Federation, contract No. 02.A03.21.0011.

\section{REFERENCES}

Baumann, C., Burton, S., Elliott, G., \& Kehr, H.M. (2007). Prediction of attitude and behavioural intentions in retail banking. Int. J. Bank Mark, 25(2), 102-116.

Berry, L., Carbone, P., \& Haeckel, H. (2002). Managing the total customer experience. MIT Sloan Manag. Review, 43(3), 85-89.

Bouchon, F., \& Rawat, K. (2016). Rural Areas of ASEAN and Tourism Services, a Field for Innovative Solutions. Procedia - Social and Behavioral Sciences, 224, 44-5. 
Brida, J. G., \& Pulina, M. (2010). A literature review on the tourism led growth hypothesis. Working paper CRENoS, 201017. Sardinia: Centre for North South Economic Research, University of Cagliari and Sassari.

Brown, T., G. \& Churchill, J.P. (1993). Improving the Measurement of Service Quality. Journal of Retailing, 69, 127-139.

Chang, T., \& Horng, S. (2010). Conceptualizing and measuring experience quality: the customer's perspective. Serv. Ind. Journal, 30(14), 2401-2419.

Chen, C. M., Lee, H. T., Chen, S. H., \& Huang, T. H. (2011). Tourist behavioural intentions in relation to service quality and customer satisfaction in Kinmen National Park, Taiwan. International Journal of Tourism Research, 13, 416-432.

Chris, B. Susan, H. Hamin, H., \& Albert, N. (2017). Competitiveness vis-à-vis service quality as drivers of customer loyalty mediated by perceptions of regulation and stability in steady and volatile markets. Journal of Retailing and Consumer Services, 36, 62-74.

Demirović, D., Košić, K., Surd, V., Žunić, L., \& Syromiatnikova, A.Y. (2017). Application of tourism destination competitiveness model on rural destinations. Journal of the Geographical Institute "Jovan Cvijić" SASA, 67(3), 279-295. DOI: http://dx.doi.org/10.2298/IJGI1703279D

Frochot I. (2005). A benefit segmentation of tourists in rural areas: a Scottish perspective. Tourism Management, 26, 335-346.

Getz, D., \& Page, S. J. (1997). Conclusions and implications for rural business development. The business of rural tourism: International perspectives (pp. 191-205). London: International Thomson Business Press.

Ghobadian, A., Speller, S., \& Jones, S. (1994). Service quality: Concepts and models. International Journal of Quality \& Reliability Management, 11(9), 43-66.

Go, F. M., \& Govers, R. (2000). Integrated quality management for tourist destinations: a European perspective on achieving competitiveness. Tourism Management, 21(1), 79-88.

Hall, D. (2004). Rural tourism development in southeastern Europe: Transition and the search for sustainability. International Journal of Tourism Research, 6(3), 165-176.

Hall, D., Mitchell, M., \& Roberts, L. (2003). Tourism and the countryside: dynamic relationships. In: Hall, D., Roberts, L., Mitchell, M. (Eds.), New Directions in Rural Tourism (pp. 3-15). Ashgate, Aldershot.

Hernández-Maestro, R.M., Muñoz-Gallego., P. A., \& Requejo, L.S. (2007). The moderating role of familiarity in rural tourism in Spain. Tourism Management, 28(4), 951-964.

Idelhadj, A., Mateos, M. R., \& García, L. R. (2012). Crónica de eventos. Revista de Turismo y Patrimonio Cultural, 10(5), 651-664.

Kim, S., Knutson, B., \& Beck, J. (2011). Development and testing of the Consumer Experience Index (CEI). Manag. Serv. Quality, 21(2), 112-132.

Korsching, P. F., \& Allen, J.C. (2004). Locality based entrepreneurship: A strategy for community economic vitality. Community Development Journal, 39, 385-400.

Lane, B. (1994). What is rural tourism? Journal of Sustainable Tourism, 2(1-2), 7-21.

Lane, B. (2009). Rural tourism: an overview. In: Jamal, T., Robinson, M. (Eds.), The SAGE Handbook of Tourism Studies (pp. 354-371). Sage Publications.

Lee, S. W., \& Nam, S.Y. (2005). Agro-tourism as a rural development strategy in Korea. Journal of Rural Development, 29(6), 67-83.

Lo, M. C., Songan, P., Mohamad, A. A., \& Yeo, A. W. (2011). Rural destinations and tourists' satisfaction. Journal of Services Research, 11(2), 59-74.

Long, L. M. (1998). Culinary tourism. Lexington, K: University Press of Kentucky.

Moreira, A. C., \& Campos D. D. (2010). Assessing the challenges of service quality in the Terra Quente Transmontana, Portugal. Tourism and Hospitality Management, 16(1), 31-45. 
Moutino, L., Albayrak, T., \& Caber, M. (2012). How far does overall service quality of a destination affect customers' post-purchase behaviours? International Journal of Tourism Research, 14, 307-322.

Narayan, B., Rajendren, C., Sai, L. P., \& Gopalan, R. (2014). Dimensions of service quality in tourism - an Indian perspective. Total Quality Management, 20(1), 61-89.

Olsson, L., Friman, M., Pareigis, J., \& Edvardsson, B. (2012). Measuring service experience: applying the satisfaction with travel scale in public transport. J. Retail. Consum. Service, 19(19), 413-418.

Petrović, M., Blešić, I., Vujko, A., \& Gajić, T. (2017a). The role of agritourism impact on local community in a transitional society: a report from Serbia. Transylvanian Review of Administrative Sciences, 50, 146-163.

Petrović, M., Vujko, A., Gajić, T., Vuković, D., Radovanović, M., Jovanović, J., \& Vuković, N. (2017b). Tourism as an Approach to Sustainable Rural Development in Post-Socialist Countries: A Comparative Study of Serbia and Slovenia. Sustainability, 10(54), 2-14.

Petrović, M.D., Gelbman, A., Demirović, D., Gagić, S., \& Vuković, D. (2017c). The Examination of the Residents' Activities and Dedication to the Local Community - An Agritourism Access to the Subject. Journal of the Geographical Institute "Jovan Cvijic'" SASA, 67(1), 37-52. DOI: https://doi.org/10.2298/IJGI1701037P

Rajaratnam, S.D., Munikrishnan, U.T., Sharif, S.P, \& Nair, V. (2014). Service quality and previous experience as a moderator in determining tourists' satisfaction with rural tourism destinations in Malaysia: Sushila et al. Procedia - Social and Behavioral Sciences, 144, $203-211$.

Roberts, L., \& Hall, D. (2001). Rural tourism and recreation: Principles to practice. Wallingford.

Rozman, C., Potocnik, M., Pazek, K., Borec, A., Majkovic, D., \& Bohanec, M. (2009). A multicriteria assessment of tourist farm service quality. Tourism Management, 30, 629-637

Smith, V. L., \& Eadington R. (1992). Tourism Alternatives: Potentials and Problems in the Development of Tourism. Philadelphia: University of Pennsylvania Press.

Snieška, V. (2014). The impact of economic factors on the development of rural tourism: Lithuanian case. Procedia - Social and Behavioral Sciences, 156, 280 - 285.

Țîțu, M.A. (2016). Measuring Service Quality in Tourism Industry. Procedia-Social and Behavioral Sciences. 221, $294-301$.

Vujko, A., \& Gajić, T. (2014a). The gouverment policy impact on economic development of tourism. Ekonomika poljoprivrede, 61(3), 789-804.

Vujko, A., \& Gajić, T. (2014b). Opportunities for tourism development and cooperation in the region by improving the quality of supply - The "Danube Cycle Route" Case Study. Economic research, 27(1), 847-860.

Vujko, A., Petrović, M., Dragosavac, M., \& Gajić, T. (2016). Differences and similarities among rural tourism in Slovenia and Serbia - perceptions of local tourism workers. Ekonomika poljoprivrede, 63(4), 1459-1469.

Wang, S., \& Qu, H. (2006). A study of tourists' satisfaction determinants in the context of the Pearl River delta sub-regional destinations. Journal of Hospitality \& Leisure Marketing, 14(3), 49-62.

Wood, E.M. (2002). Ecotourism: Principles, practices \& policies for Sustainability. UNEP; International Ecotourism Society. 